\title{
Consumers' Perception on Organisational Corporate Social Responsibility Practices and its Implications on Consumer Attitude: Evidence from the Malaysian Telecommunication Industry
}

\author{
Chee Yoong Liew ${ }^{1} \&$ Bee Lian Song ${ }^{1}$ \\ ${ }^{1}$ Faculty of Business, Accounting and Management, SEGi University, Malaysia \\ Correspondence: Chee Yoong Liew, Faculty of Business, Accounting and Management, SEGi University, No. 9, \\ Jalan Teknologi, Taman Sains Selangor, Kota Damansara, PJU5, 47810 Petaling Jaya, Selangor, Malaysia. \\ E-mail: liewcheeyoong@segi.edu.my
}

Received: September 30, 2017

Accepted: October 28, 2017

Online Published: November 5, 2017

doi:10.5539/jms.v7n4p112

URL: http://doi.org/10.5539/jms.v7n4p112

\begin{abstract}
This paper aims at investigating consumers' perception on the Corporate Social Responsibility (CSR) practices of the telecommunication service companies in Malaysia, and its antecedent to consumer attitude. The local telecommunication service providers have emphasized on service quality, stakeholder value, corporate reputation, and innovation to achieve good business performance. However, little is known about the contribution of service quality, stakeholder value, corporate reputation, and innovation on the effectiveness of organisational CSR practices. Furthermore, lack of previous studies that have investigated the impact of organisational CSR practices on consumer attitude, particularly in the context of Malaysian telecommunication industry. With the adoption of structural equation modeling approach and survey method, a total of 360 samples comprising the prepaid and postpaid mobile consumers were obtained for this study. The results shown that consumers' perception on service quality and stakeholder value had significant relationship with CSR practices. However, consumers' perception on corporate reputation and innovation had no significant relationship with CSR practices. CSR practices was positively related to consumer attitude. In the theoretical implications, service quality and stakeholder value variables were found as important elements in the proponents of Strategic CSR Theory. In the managerial implications, this study recommended that the telecommunication service providers should highly focus on more effective planning and implementation of CSR practices through better integration of CSR in its core business functions and value chain system, diversification of CSR scope and stakeholders engagement.
\end{abstract}

Keywords: corporate social responsibility, consumers' perception, service quality, corporate reputation, stakeholders

\section{Introduction}

CSR is playing an important role in the rapidly changing global world. Climate change, water and food scarcity, child poverty, labor discrimination, pollution - all these issues are increasingly being prioritised along with business performance. It has becoming more difficult and challenging for companies to sustain business as usual due to resource scarcity, natural disasters or social issues, which raise costs and endanger operations (Ellis, 2010). Furthermore, the changing expectations and demands of a broad range of stakeholders, including regulators, investors, employees, consumers and society, at large have contributed to increasing pressure towards the companies. Stakeholders are demanding to know how companies contribute to wealth creation for everyone by building a sustainable world, not just sustainable business. The World Business Council for Sustainable Development defines CSR as "commitment of business to contribute to sustainable economic development, working with employees, the local community and society" (World Business Council for Sustainable Development, 2000). Today, companies are facing challenging roles by getting their own strategy to take part in today's interests of society and customer, as well as being responsible for social needs and sustainable use of resources. These have leads to companies across the globe are focusing on improvement of their environmental and social commitment by using different strategies and channels through effective CSR practices. Hence, globalisation is the main factor that has caused CSR as an important catalyst in the contemporary challenging environment. CSR is increasingly needed to handle and resolve the arising global issues and this has leads to CSR as the forefront of today's global agenda. 
In the wake of globalisation, the emergence of ethical consumers in the market has evolved the way businesses produce or selling their products or services. The ethical consumers are consumers who are more selective and conscious about the products or services that they are purchasing and consuming, as well as take into consideration of social responsibilities elements when making purchase decisions. Several research studies have revealed that the ethical consumers have emerged (Hendarwan, 2002; Freestone \& McGoldrick, 2008) and have taken ethical, environmental and social issues into account when buying products or services (Uusitalo \& Oksanen, 2004; Marin, Ruiz, \& Rubio, 2009). Hence, companies that successfully engaged CSR have been proven of achieving long-term benefits of brand enhancement, competitive advantage, goodwill, increased employees motivation, quality workforce retention, consumer loyalty, higher profitability and better performance (Nastanski \& Baglione, 2014; Lantos, 2001; Davies, 2003; Maignan \& Ferrell, 2004).

The competitions between the telecommunication service providers in Malaysia is getting more intense (NST, 2016). Malaysia Communications and Multimedia Commission (MCMC, 2017) reported that the total cellular telephone subscribers in Malaysia have reached 43.9 million at the end third quarter of 2016. In view of the huge consumer base and increasing competitions, the power of consumers in the telecommunication industry and their impact on the success of a business are considered strong. Besides improving its service, network coverage, quality customer service, packages development and other areas of operations, CSR are increasing used as a catalyst for organisational positive change, attract and retain consumers, improve branding and achieve business sustainability. For example, DiGi has successfully integrated CSR into their strategic business plan through the focus areas of empowering communities through connectivity; climate change; and responsible and safe business practices (DiGi, 2016). Maxis has initiated their CSR practices in the aspect of community development, environmental programmes, employee development and philanthropic (Maxis, 2017). As for Celcom, engagement in charity drives, employee development and environmental programmes are among their CSR initiatives (Celcom, 2017). Despite allocated and invested substantial amount of resources and efforts into CSR practices, however, the outcome results remain skeptical. Little is known pertaining to the impact of CSR practices towards the important stakeholders' perception, decision making and engagement with the organisations (Dilling, 2011). Consumers are considered as the most important stakeholder of an organisation because they pave the way for business achievements in the aspect of financial, growth and reputation. Hence, it is important to investigate on to what extent consumers perceived organisational CSR and how this would affect their attitude towards the organisation. However, weak organisational CSR practice and engagement will risk stakeholders' interest, business performance and sustainability.

The primary objectives of this study are; 1) to investigate the effect of service quality, stakeholder value, corporate reputation, and innovation on organisational CSR practices and 2) to analyse the influence of organisational CSR practices towards consumer attitude. The findings of this research will contribute to managerial and theoretical implications. In the aspect of managerial implications, the research findings will provide valuable information to the telecommunication service providers in effective planning and implementation of CSR practices. This study will also provide extension to the Strategic CSR theory by investigating the proponents of CSR representing the selected variables of service quality, stakeholder value, corporate reputation, and innovation.

\section{Literature Review and Hypotheses Development}

\subsection{Strategic CSR Theory}

Porter \& Kramer (2002) advocated Strategic CSR theory, which aligns an organisation's value, business plan and core competencies with a social agenda to benefit both the society and business. Strategic CSR theory was further developed based on the "share-value" concept (Porter \& Kramer, 2011). Based on the concept of "shared value", CSR practices can enhance the competitiveness of companies while simultaneously advancing environmental and social conditions. Organisation could achieve competitive advantage through effective strategic CSR. Porter \& Kramer further elaborated that the proponents of CSR are moral obligation, sustainability, license to operate and reputation (Porter \& Kramer, 2006). The moral obligation refers to the company's responsibility of "doing the right thing" for the society. According to Carroll (2016), the fundamental responsibility of businesses is to produce product or service that meet the needs and desires of the society. In this respect, businesses have moral duties to consumers by ensuring product or service that customer buy is of sufficient quality (Gray, 2011).

Another proponents of Strategic CSR theory is sustainability, which emphasizes on environmental and community stewardship. Every company needs permission from authorities, communities and other stakeholders to do business and maintain its license to operate. For business sustainability, it is important for companies to fulfill the stakeholders' interest though effective stakeholder value creation (Harrison \& Wicks, 2013). 
Reputation is used to justify CSR initiatives to improve a company's image, strengthening the brand and even raise the value of its stock (Porter \& Kramer, 2006). Strategic CSR theory is applied in this study with the proponents of CSR representing the selected variables of service quality, stakeholder value, corporate reputation, and innovation. Service quality and innovation represents the moral obligation of the organisation, followed by stakeholder value represents license to operate and sustainability, and corporate reputation represents reputation. All these selected proponents of CSR will be investigated based on its effect towards organisational CSR practices and subsequently, consumer attitude.

\subsection{Service Quality}

Perceived quality is defined as "the customer's judgment about a product's overall excellence or superiority that is different from objective quality" (Zeithaml, 1988). Perceived quality is also viewed as the degree and direction of discrepancy between consumers' perception and expectation. Customers' assessment of overall product or service quality is based on the gap between their expectations and their perceptions of performance levels or service actually received. SERVQUAL model is widely applied to measure the five elements of quality, which is tangibility, reliability, responsibility, assurance and empathy (Parasuraman, Zeithaml, \& Berry, 1985). Consumer evaluation of product or service quality involving the tangible and intangible factors. Tangible aspects include features, packaging, equipment, personnel, and communications material. Intangibles aspect include reliability, branding, responsiveness, assurance, safety and empathy (Parasuraman et al., 1985; Nadiri \& Hussain, 2005).

Poolthong \& Mandhachitara (2009) found that CSR initiatives positively influenced consumers' perception on service quality, which in turn, also influenced trust and brand effect. In contrast, several studies reported consumers' perceived that organisational product or service quality does not influenced CSR practices. Seo, Moon, \& Lee (2015) conducted a study in the airline industry, they found that exist a positive synergistic effect of service quality and CSR for full service carriers. As a result, the following hypothesis is developed:

\section{$H_{1}$ : There is a positive relationship between service quality and CSR practices.}

\subsection{Stakeholder Value}

Stakeholder theory advocates that companies have a social responsibility that requires them to consider the interests of all parties affected by their actions (Branco \& Rodrigues, 2007). The concepts of stakeholder and CSR are closely linked to each other (Pirsch, Gupta, \& Grau, 2007). The stakeholder theory has been linked to the CSR development of the firm in view that CSR create values to the stakeholder parties.

Previous studies have shown positive relationship between organisational generated good values to the stakeholders and its CSR practices (Dusuki \& Dar, 2005; Kapur \& Sengupta, 2011). The evidence that supported these findings were based on the firms that were successful in contributing good values to their stakeholders, and also strong stakeholders' engagement process in place with good CSR practices as well. Dusuki \& Dar (2005) conducted a survey on the stakeholders of the Malaysian Islamic banking sector to evaluate the stakeholders' perceptions toward CSR practices of the banks. They found that the stakeholders perceived organisational CSR practices have created positive values to them, and subsequently generated positive attitude of the stakeholders towards the banks. Firms that were successful in generating good values to its stakeholders were also reflect their good ability in satisfying its stakeholders' interest. As a result, the following hypothesis is developed:

\section{$\mathrm{H}_{2}$ : There is a positive relationship between stakeholder value and CSR practices.}

\subsection{Corporate Reputation}

Corporate reputation is defined as "the overall estimation in which a company is held by its constituents, that is the net affective or emotional reaction - good or bad, weak or strong — of customers, investors, employees, and the general public to a company's name" (Fombrun, 1996). The building of corporate reputation is complex and time consuming, which is similar to the efforts given on the development of product or service, building consumers' trust and achieving sustainable business (Eberl \& Schwaiger, 2005). According to McGuire et al. (1988), a firm has an investment in reputation, including its reputation for being socially responsible. There were numerous past studies pertaining to consumers' perception of the corporate reputation and its relationship with CSR practices. Some researchers have concluded that exist positive relationship between corporate reputation and CSR practices (Du, Bhattacharya, \& Sen, 2009; Awang \& Jusoff, 2005). Firms with good reputation are most likely to be actively involved in CSR practices to sustain and also further boost its reputation and image.

One of the core components of corporate reputation is a corporate brand (Abratt \& Kleyn, 2012). An ethical brand enhances the corporate reputation, as well as reputation reinforces the brand in turn (Fan, 2005). Any unethical behaviour will severely damage or even destroy the total intangible asset of branding as evidenced by the recent high profile corporate scandals (Fan, 2005). A strong brand with ethical concerns is counted as a 
valuable asset of a company to achieve good corporate reputation (Hoq, Ali, \& Alwi, 2010).

Companies are increasingly adopting responsible business behavior and acknowledging the importance of accountability and disclosure to achieve good corporate reputation. The high emphasize on transparency and accountability towards the organisational stakeholders helps in building trust from the stakeholders and improve corporate reputation. Most of the telecommunication service providers in Malaysia have emphasized highly on CSR reporting and disclosure. Their initiatives have positively influenced consumers' perception on the firms in the aspect of good governance and responsible corporate citizen. For example, DiGi prepared their Sustainability Report on annual basis to disclose CSR commitments and achievements to its important stakeholders. Lange, Lee \& Dail (2011) stressed on the need to investigate organisational reputation as multidimensional and to model its antecedents and effects. Hence, this study will bridge the literature gaps by investigating the organisation reputation as antecedent to CSR practices and its effect on consumer attitude.

$H_{3}$ : There is a positive relationship between corporate reputation and CSR practices.

\subsection{Innovation}

Kanter (1999) advocated that "winning in business today demands innovation". In today's competitive business environment, innovations are crucial for businesses to survive. The position as the leader of the market often largely depends on the extent of organisational efficiency in managing innovation. A number of studies have found that innovation positively influenced CSR practices through the creation in new ways of working, new products, services, processes and new market space that leverages on social and environmental friendly mechanism (Grayson \& Hodges, 2004; Little, 2006). Hence, firms that prioritised on innovation as their core business activity will also drive or have effective and good CSR practices. This is based on the fact that firms are leveraging on business sustainability practices. Grayson \& Hodges (2004) stated that the driver for business success is entrepreneurialism, a competitive instinct and a willingness to look for innovation from non-traditional areas such as those increasingly found within the CSR agenda. These opportunities are described as "commercially viable activities which also advance environmental and social sustainability". Three dimensions of corporate social opportunity are innovation in products and services, serving niche markets and building new business models. For example, a few local telecommunication providers involves their important partners and suppliers in the green procurement programme, usage of environmental friendly products and eco-friendly innovation. This leads to innovation values were created that enhance the quality of product or services offered by the firms.

Innovation is measured based on the firm's commitment in providing continuous improvement of its products or services to the customers. According to Hamel \& Prahalad (1994), strategic renewal or better known as strategic innovation or value innovation (Kim \& Mauborgne, 2005), should leverage on CSR initiatives. However, under certain circumstances organisational innovation does not majorly or positively influenced CSR practices. The industry type, size of the firm, location and even business cycle are among the main factors that would determine the extent of firm's innovation strategic plan and initiatives (Shavinina, 2003). In this respect, the following hypothesis is developed:

\section{$\mathrm{H}_{4}$ : There is a positive relationship between innovation and CSR practices.}

\subsection{Consumer Attitude}

An attitude is "a tendency or disposition to respond favourably or unfavourably to an entity"; for example, an event, situation or individual (Eagly \& Chaiken, 1993). CSR initiatives indeed have a strong influence on consumer attitude and behavior towards products and companies (Sen \& Bhattacharya, 2001). Rivera, Bigne, \& Curras-Perez (2015) found a positive direct relationship between CSR and customer satisfaction based on organisational environmental initiatives. The effectiveness of organisational CSR practices will drive consumers' purchasing decisions through criteria of price, quality and service (Swaen \& Chumpitaz, 2008). Companies that simultaneously do good and innovate are rewarded with more positive customer attitudes and higher levels of customer retention. In a study conducted on bank customers in the Czech Republic by Paulik, Kombo, \& Ključnikov (2015), they found that CSR strategy does not have significant influenced on consumer attitude in the aspect of satisfaction. Hence, the following hypothesis is developed:

\section{$H_{5}$ : There is a positive relationship between CSR practices and customer attitude.}

The independent variables were represented by the organisational aspects of service quality, stakeholder value, corporate reputation and innovation. The mediating variable was represented by the organisational CSR practices, and consumer attitude as the dependent variable. The conceptual framework for this study is shown in Figure 1. 


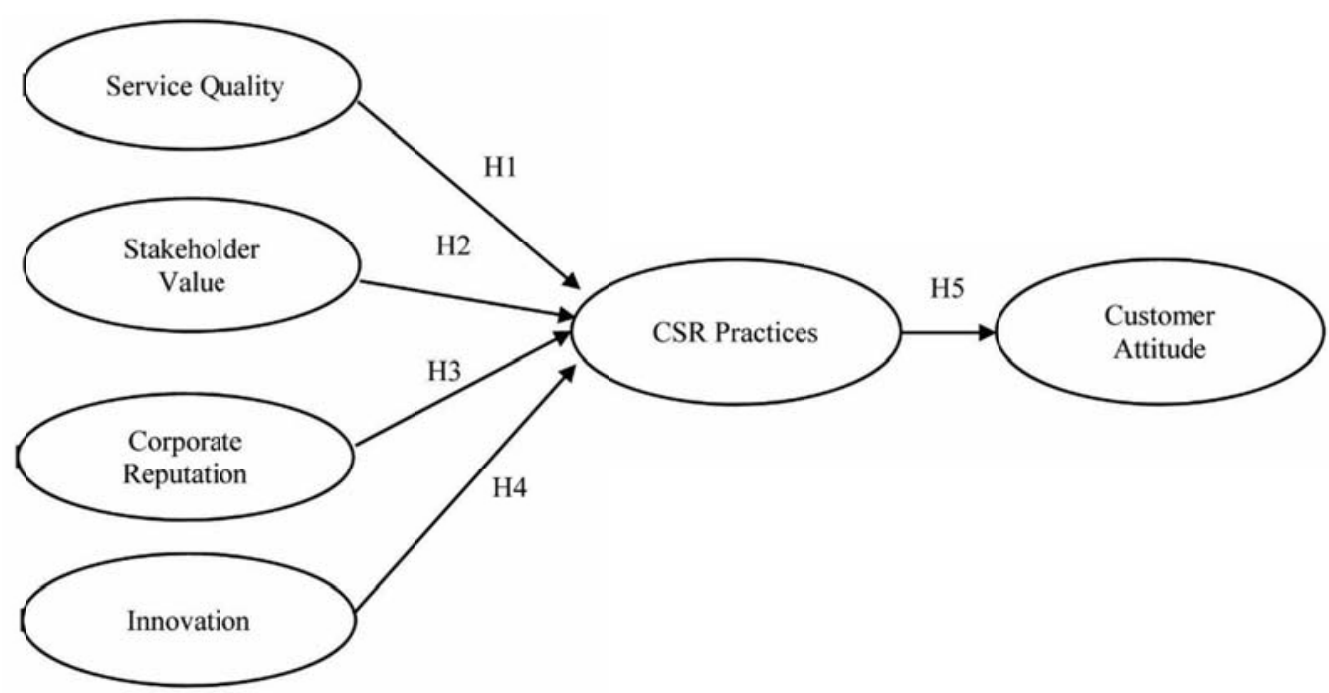

Figure 1. Conceptual framework

\section{Research Methodology}

\subsection{Sampling and Measurement}

The population of this research was individual residing in Malaysia aged 18 and above who are existing post-paid and pre-paid consumer of Digi, Maxis, and Celcom. Hair, Black, Babin, \& Anderson (2010) suggested that a minimum sample size of 300 is required for Structural Equation Modeling (SEM) analysis for less than seven constructs in the structural model. We have determined a sample size of 360 for this study to meet the requirement for SEM analysis and to achieve generalisation of the findings. Through non-probability convenience sampling method, self-administered questionnaires were distributed to consumers present at the selected outlets of Digi, Maxis, and Celcom in Kuala Lumpur and Selangor, Malaysia. The survey instrument was designed with 27 items assessed by a six-point Likert scale (1: strongly disagree and 6: strongly agree) and demographic variable with 4 items. The scale measured service quality, stakeholder value, corporate reputation, innovation, CSR practices, and consumer attitude. Statistical Package for Social Sciences (SPSS) version 22 was used to perform descriptive analysis, validity and reliability analysis. Subsequently, SPSS AMOS version 21 was used to perform the SEM analysis to test the hypotheses.

\subsection{Validity and Reliability Assessment}

The pilot study results indicated the factor loading for all the 27 proposed items is above 0.3 and thereby will be retained (Hair, Black, Babin, \& Anderson, 2010). The Cronbach's Alpha values for all constructs were above 0.7 which have shown a high level of internal consistency in the data (Pallant, 2007). The Cronbach's Alpha values were 0.932 (Service Quality), 0.843 (Stakeholder Value), 0.901 (Corporate Reputation), 0.881 (Innovation), 0.898 (CSR Practices) and 0.870 (Customer Atttitude). Table 1 shows the results of Confirmatory Factor Analysis (CFA) for each item in the construct and the reliability test results. The pilot study results showed that all the constructs were valid and reliable for further inferential analyses. 
Table 1. CFA results for the measurement model

\begin{tabular}{|c|c|c|c|c|}
\hline Construct & Item & Statement & $\begin{array}{l}\text { Factor } \\
\text { Loading }\end{array}$ & $\begin{array}{l}\text { Cronbach's } \\
\text { Alpha }\end{array}$ \\
\hline Service & S1 & Excellent customer service provided. & .840 & .932 \\
\hline \multirow[t]{4}{*}{ Quality } & S2 & Integrated environmental-friendly approach in service delivery. & .896 & \\
\hline & S3 & Offered reliable services. & .906 & \\
\hline & S4 & Services offered meet my expectations. & .855 & \\
\hline & S5 & My service provider fulfils its obligations to customer. & .783 & \\
\hline Stakeholder & V1 & Prioritise in satisfying stakeholders' interest. & .672 & .843 \\
\hline \multirow[t]{4}{*}{ Value } & $\mathrm{V} 2$ & Sustainable ethical business practices with stakeholders. & .721 & \\
\hline & V3 & Build strong trust with stakeholders. & .708 & \\
\hline & V4 & Good involvement of stakeholders in CSR practices. & .816 & \\
\hline & V5 & Provided good support to stakeholders. & .692 & \\
\hline Corporate & $\mathrm{C} 1$ & Overall, my service provider has good corporate reputation. & .742 & .901 \\
\hline \multirow[t]{3}{*}{ Reputation } & $\mathrm{C} 2$ & Excellent brand image. & .928 & \\
\hline & $\mathrm{C} 3$ & Good reputation for being socially responsible company. & .907 & \\
\hline & $\mathrm{C} 4$ & Transparent CSR reporting and disclosure. & .779 & \\
\hline \multirow[t]{4}{*}{ Innovation } & N1 & Continuous service improvement services to the customers. & .697 & .881 \\
\hline & $\mathrm{N} 2$ & Good involvement of customers in service innovation/ development. & .912 & \\
\hline & N3 & $\begin{array}{l}\text { Leverage on new technologies and approaches for products/services } \\
\text { improvements. }\end{array}$ & .876 & \\
\hline & $\mathrm{N} 4$ & Effective in social innovation. & .761 & \\
\hline CSR & $\mathrm{P} 1$ & Overall, active in CSR activities. & .749 & .898 \\
\hline \multirow[t]{4}{*}{ Practices } & $\mathrm{P} 2$ & Provide services that meet society needs at reasonable pricing. & .788 & \\
\hline & P3 & Comply well with the law requirement. & .883 & \\
\hline & P4 & Ethical in its operations. & .895 & \\
\hline & P5 & Contributes to the charitable causes and community developments. & .627 & \\
\hline Customer & A1 & Overall, positive attitude towards current service provider. & .817 & .870 \\
\hline \multirow[t]{3}{*}{ Attitude } & $\mathrm{A} 2$ & Maintain loyal to current service provider. & .800 & \\
\hline & A3 & My service provider is first choice among other service providers. & .785 & \\
\hline & A4 & $\begin{array}{l}\text { Intention to purchase extra other service or package from my current } \\
\text { service provider. }\end{array}$ & .762 & \\
\hline
\end{tabular}

\section{Results}

\subsection{Demographic Profile of the Respondents}

Respondents in this research were 360 existing consumers from the three selected telecommunication service providers in Malaysia. Majority respondents were female with $58.3 \%$, and male with $41.7 \%$. The age category of majority respondents were between $39-49$ with $49.4 \%$ from the total respondents. Majority respondents of $42.2 \%$, were under income category of RM3,000-RM6,000. Post-paid customers were 62\%, while the pre-paid customers were $38 \%$. The demographic profile of respondents are presented in Table 2.

Table 2. Respondents' demographic profile

\begin{tabular}{lll}
\hline Demographic Variables & Frequency (n) & Percentage (\%) \\
\hline Gender & & \\
Male & 150 & 41.7 \\
Female & 210 & 58.3 \\
Age & & \\
$18-20$ & 32 & 8.9 \\
$21-38$ & 92 & 25.6 \\
$39-49$ & 178 & 49.4 \\
$\geq 50$ & 58 & 16.1 \\
Income & & \\
<RM1500 & 18 & 5.0 \\
RM1500- RM3000 & 49 & 13.6 \\
RM3000-RM6000 & 152 & 42.2 \\
RM6000-RM10000 & 112 & 31.1 \\
$>$ RM10000 & 29 & 8.1 \\
Type of Customers & & \\
Post-paid & 223 & 62.0 \\
Pre-paid & 137 & 38.0 \\
\hline
\end{tabular}




\subsection{Model Compatibility Testing}

SEM was applied to estimate the relationships between service quality, stakeholder value, corporate reputation, innovation, CSR practices, and consumer attitude using the maximum likelihood procedure. The research model has achieved a good fit as shown in Table 3. The Chi-Square value is 689.058 and according to Barrett (2007), chi square probability value greater than 0.05 indicates acceptable model fit. The ratio of $x^{2} / \mathrm{df}$ was 2.201 , lower than the value 3.0, as suggested by Byrne (2001). Incremental fit indices were greater than 0.9, with IFI of 0.940, CFI of 0.940 and TLI of 0.933 . The absolute index with RMSEA of 0.058 , achieved lower than 0.8 (Browne \& Cudeck, 1993).

Table 3. Goodness of fit

\begin{tabular}{llll}
\hline Index & Level of Acceptance & Result & Model Evaluation \\
\hline Chi-square & P $>0.05$ & 689.058 & Good \\
Chisq/df & Chi Square $/$ df $<3.0$ & 2.201 & Good \\
RMSEA & RMSEA $<0.08$ & 0.058 & Good \\
IFI & IFI $>0.9$ & 0.940 & Good \\
CFI & CFI $>0.9$ & 0.940 & Good \\
TLI & TLI $>0.9$ & 0.933 & Good \\
\hline
\end{tabular}

The normality assessment was conducted and indicated that the data is normally distributed with value of skewness between -1.0 and 1.0, and kurtosis of between -3.0 and 3.0. Finally, the estimated path coefficients were derived and the research hypotheses were examined.

\subsection{Model Causality Testing}

The final structural model is shown in Figure 2.
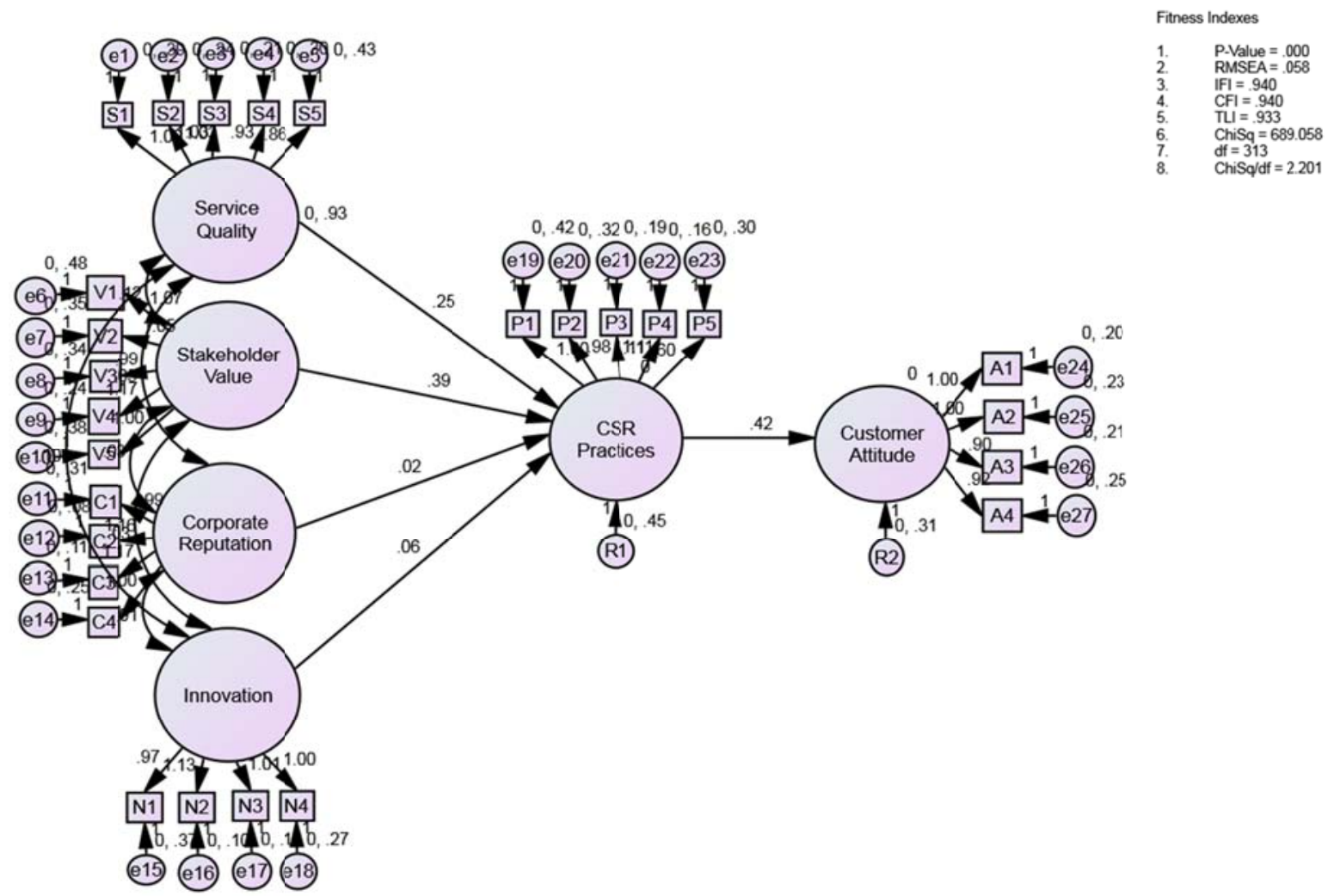

Figure 2. Final structural model 
The regression weights and probability value which indicates its significance is shown in Table 4 . The results shown that service quality had significant positive effect $(0.253)$ on CSR practices and $\mathrm{H}_{1}$ is accepted. $\mathrm{H}_{2}$ is accepted and stakeholder value has significant effect on CSR practices (0.389). The regression coefficient of the relationship between corporate reputation and CSR practices is not significant $(0.024)$. As a result, $\mathrm{H}_{3}$ is rejected. The regression coefficient of the relationship between innovation and CSR practices is also not significant (0.061) and $\mathrm{H}_{4}$ is rejected. Subsequently, CSR practices had positive effect $(0.422)$ on customer attitude, and $\mathrm{H}_{5}$ is accepted.

Table 4. Regression weights and the probability value which indicates its significance

\begin{tabular}{llllllll}
\hline Paths & & & Estimate & S.E. & C.R. & P & Result \\
\hline CSR Practices & $<--$ & Service Quality & .253 & .044 & 5.721 & $* * *$ & Supported \\
CSR Practices & $<--$ & Stakeholder Value & .389 & .077 & 5.074 & $* * *$ & Supported \\
CSR Practices & $<--$ & Corporate Reputation & .024 & .063 & .386 & .699 & Rejected \\
CSR Practices & $<--$ & Innovation & .061 & .066 & .925 & .355 & Rejected \\
Customer Attitude & $<--$ & CSR Practices & .422 & .050 & 8.451 & $* * *$ & Supported \\
\hline
\end{tabular}

\section{Discussion}

This study has contributed to theoretical implications, service quality and stakeholder value variables were found as the elements in the proponents of Strategic CSR Theory. The shared value concept is extended through service quality represented moral obligations, and stakeholder value represented sustainability and license to operate. Furthermore, consumer attitude is found as the behavioural outcome in the Strategic CSR Theory application. As discussed, firms implemented effective CSR practices would gain advantages in the aspect of competitive advantage, growth, profitability, branding, customer loyalty, employee motivation, and other aspects. Positive consumer attitude is closely related to achieving customer loyalty. Hence, this study has extended the Strategic CSR theory through more in-depth understanding on the shared value concept with the important antecedents of service quality and stakeholder value effect towards CSR practices, as well as its behavioral outcome measurement from the customer attitude perspective.

The findings indicated that the local telecommunication providers have moved beyond traditional philanthropic initiatives to a wider range of CSR practices comprising combination of economic, legal, ethical and philanthropic. Nevertheless, the service providers should give greater attention and more commitment towards CSR practices. It was suggested that firms should continuously maintain and enhance its CSR practices through diversification of CSR scope and activities to achieve more positive perception and attitude from the consumers, and to improve business performance. To stay competitive in the telecommunication industry, the service providers should leverage on innovative, new and diverse CSR practices which are related to build organisational reputation and image, product or service quality and stakeholders' value. As highlighted by Prahalad \& Hamel (1990), continuous renewal strategies could be applied to continuously enhance CSR practices according to the competitive business environment. Firm must not only protect its existing business practices, but also must leverage on new market segment, build new capabilities and transform into new business through the adoption of CSR. CSR should be utilised as an "opportunity for renewal" (Manubens, 2009). Firm should be sensitive to the global CSR trend and development when planning and implementing CSR continuous renewal strategies.

To increase business performance and achieve business sustainability, company should formulate effective strategic policies by integrating CSR based on the company background, culture, peculiarity in relationship with its different stakeholders so that CSR can be best implemented towards its goals-sustained environmental, social and economic growth. Well structured, planned and implemented CST activities will drive maximum impact and enhance the well-being of the beneficiaries. It is important for companies to develop an effective value chain system of their products or services through their CSR activities, which would in return help boost reputation and image, service quality, stakeholder value and innovation to sustain competitive advantage. Hence, there is also a need for public-private partnership with well-defined controls and process for the effective use of resources for social change. For example, the local telecommunication providers can leverage on CSR partnership with wider range of non-government organisations (NGOs). Experience has shown that working with NGOs is more worthwhile and result-oriented.

The links between innovation and CSR could further enhance by corporate social innovation through green innovation, produce products or services that would improves the quality of life and targeting different market 
segments. Firm should transform CSR into corporate social innovation (CSI) through changing social issues into business issues. As highlighted by Kim, Brodhag, \& Mebratu (2015), innovative investment is not limited to investments in technology and in R\&D, but also sustainability to human, social, environmental, technical, and economic investments. Business strategy is a pledge to improve its environmental practices by focusing technologies, production capacity and infrastructure on developing solutions. Companies should revitalize their business models by putting innovation and sustainability at the core of their business thinking (Ellis, 2010). Hence, the service providers should ensure that investments in CSR business practices are made and engaged consistently over long periods of time. According to Dilling (2011), consumers' perception on CSR is higher if companies publish a separate sustainability or CSR report. Therefore, communication is essential to show their strong commitment towards CSR practices to external and internal parties. By taking into consideration of the highlighted recommendations, consumers' perception and attitude towards the service providers will be more positive, and subsequently, leads to better post-purchase consumer behavioral.

\section{Conclusions}

There are several limitations associated with this research. Among the limitations are the target sample focused on the mobile phone consumers of the telecommunication service providers in Malaysia. Future studies could extend the consumer types, i.e., broadband, home internet and others, to enhance the generality of the results. Also, future studies may extend the investigation to different industries and countries for comparative study. Further research could also focus on other important stakeholders, such as employees, investors and local communities. In view that consumers constitute a major stakeholder group, other stakeholders' insights on organisational CSR practices are equally important as well. More comprehensive perceptions of the organisational CSR could be obtained through inclusive of various stakeholders in the study. The study on consumers' perception does not limit to the components of service quality, stakeholder value, corporate reputation, and innovation. However, there are other aspects of consumers' perception that should be explored in future, such as organisation financial performance, management capability, service improvements, communications efficiency or marketing strategies.

\section{References}

Abratt, R., \& Kleyn, N. (2012). Corporate identity, corporate branding and corporate reputations: Reconciliation and integration. European Journal of Marketing, 46(7/8), 1048-1063. https://doi.org/10.1108/03090561211230197

Awang, Z. H., \& Jusoff, K. (2005). The Effects of Corporate Reputations on the Competitiveness of Malaysian Telecommunications Service Provider. International Journal of Business and Management, 4(5), 173-178. http://dx.doi.org/10.5539/ijbm.v4n5p173

Barrett, P. (2007). Structural equation modelling: Adjudging model fit. Personality and Individual Differences, 42, 815-824. http://dx.doi.org/10.1016/j.paid.2006.09.018

Branco, M. C., \& Rodrigues, L. L. (2007). Positioning Stakeholders Theory within The Debate of Corporate Social Responsibility. Journal of Business Ethics and Organisational Studies, 12(1), 5-13.

Browne, M. W. \& Cudeck, R. (1993). Alternative ways of assessing model fit. In K. A. Bollen \& J. S. Long (Eds.), Testing structural equation models (pp. 136-161). Newbury Park, CA: Sage.

Carroll, A. B. (2016). Carroll's pyramid of CSR: taking another look. International Journal of Corporate Social Responsibility, 1(3). https://doi.org/10.1186/s40991-016-0004-6

Celcom. (2017). Corporate Website. Retrieved from http://www.celcom.com.my/

Davies, R. (2003). Social Responsibility and Corporate Values, in Making Globalization Good: The Moral Challenges of Global Capitalism (Edited by J. H. Dunning, pp. 301-319). Oxford, Oxford University Press.

DiGi. (2016). Sustainability Report. Retrieved from http://www.digi.com.my

Dilling, P. F. A. (2011). Stakeholder Perception of Corporate Social Responsibility. International Journal of Management and Marketing Research, 4(2), 23-34.

Du, S., Sen, S., \& Bhattacharya, C. B. (2009). Building Relationships through Corporate Social Responsibility. In D. J. MacInnis, C. W. Park, \& J. R. Priester \& M. E. Sharpe (Eds.), Handbook of Brand Relationships.

Dusuki, A. W., \& Dar, H. (2005). Stakeholders' Perceptions of Corporate Social Responsibility of Islamic Banks: Evidence from Malaysian Economy. Retrieved from http://www.kantakji.com/media/9439/stakeholders\%E2\%80\%99-perceptions-of-corporate.pdf 
Eagly, A. H., \& Chaiken, S. (1993). The psychology of attitudes. Fort Worth, TX: Harcourt Brace Jovanovich College Publishers.

Eberl, M., \& Schwaiger, M. (2005). Corporate reputation: disentangling the effects on financial performance. European Journal of Marketing, 39(8), 838-854. https://doi.org/10.1108/03090560510601798

Ellis, T. (2010). The New Pioneers: Sustainable business success through social innovation and and Social Entrepreneurship. London: Wiley.

Fan, Y. (2005). Ethical Branding and Corporate Reputation. Corporate Communication: An International Journal, 10(4), 341-350.

Fonbrun, C. (1996). Reputation: Realizing Value from the Corporate Image. Boston: Harvard Business School Press.

Freestone, O. M., \& McGoldick, P. J. (2008). Motivation of the ethical consumer. Journal of Business Ethics, 79(4), 445-467.

Gray, J. W. (2011). Moral Issues Related to Consumers. Retrieved from https://ethicalrealism.wordpress.com/2011/05/16/moral-issues-related-to-consumers/

Grayson, D., \& Hodges, A. (2004). Corporate Social Opportunity!: Seven Steps to Make Corporate Social Responsibility Work for your Business. Greenleaf, Sheffield.

Hair, J. F., Black, W. C., Babin, B. J., \& Anderson, R. E. (2010). Multivariate Data Analysis: A global perspective (7th ed.). New Jersey, NJ: Pearson Education Inc.

Hamel, G., \& Prahalad, C. K. (1994). Competing for the Future. Boston, MA: Harvard Business School Press.

Harrison, J. S. \& Wicks, A. C. (2013). Stakeholder Theory, Value and Firm Performance. Business Ethics Quarterly, 23(1), 97-124. https://doi.org/10.5840/beq20132314

Hendarwan, E. (2002). Seeing Green. Global Cosmetic Industry, 170(5), 16-18.

Hoq, M. Z., Ali, S. M. \& Alwi, S. F. (2010). The Role of "Ethical Brand" and Its Effects on Company Reputation. Administration and Management Review, 22(1), 60-73.

Kanter, R. M. (1999). From Spare Change to Real Change. Harvard Business Review, 77(3), 122-132.

Kapur, V. \& Sengupta, E. (2011). CSR and Good Practices of Stakeholders Engagement: A Case Study of Cross Ethnic Business Relation in Nagaland. Asian CSR and Sustainability Review, 2(1), 61-67.

Kim, W. C., \& Mauborgne, R. (2005). Value innovation: a leap into the blue ocean. Journal of Business Strategy, 26(4), 22-28. https://doi.org/10.1108/02756660510608521

Kim, Y., Brodhag, C., \& Mebratu, D. (2014). Corporate social responsibility driven innovation. The European Journal of Social Science Research, 27(2), 175-196.

Lange, D., Lee, P. M., \& Dail, P. (2011). Organizational Reputation: A Review. Journal of Management, 37(1), 153-184. https://doi.org/10.1177/0149206310390963

Lantos, G. P. (2001). The boundaries of strategic corporate social responsibility. Journal of Consumer Marketing, 18(7), 595-630. https://doi.org/10.1108/07363760110410281

Little, A. D. (2006). The Innovation High ground - Winning tomorrow's customers using sustainability-driven innovation. Strategic Direction, 22(1), 35-37. https://doi.org/10.1108/02580540610635942

Maignan, I., \& Ferrell, O. C. (2004). Corporate Social Responsibility and Marketing: An Integrative Framework. Journal of the Academy of Marketing Science, 32(1), 3-19.

Marin, L., Ruiz, S. \& Rubio, A. (2009). The role of Identity salience in the effects of Corporate Social Responsibility on Consumer Behavior. Journal of Business Ethics, 84(1), 65-78.

Maxis. (2017). Corporate Website. Retrieved from http://www.maxis.com.my

McGuire, J. B., Sundgren, A., \& Schneeweis, T. (1988). Corporate social responsibility and firm financial performance. Academy of Management Journal, 31(4), 854-872. http://dx.doi.org/10.2307/256342

MCMC. (2017). Corporate website. Retrieved from http://www.skmm.gov.my

Nadiri, H., \& Hussain, K. (2005). Perceptions of service quality in north Cyprus hotels. International Journal of Contemporary Hospitality Management, 17(6), 469-480. https://doi.org/10.1108/09596110510612112

Nastanski, M., \& Baglione, S. L. (2014). Sustainability: Benefits of Social Responsibility to Brand Value \& 
Profit. The Journal of International Management Studies, 9(2), 164-173.

NST. (2016). Competition hots up for Big 3 telcos. Retrieved from https://www.nst.com.my/news/2016/05/145535/competition-hots-big-3-telcos

Pallant, J. (2007). SPSS Survival Manual. Maidenhead: Open University Press.

Parasuraman, A., Zeithaml, V. A., \& Berry, L. L. (1985). A conceptual model of service quality and its implications for future research. Journal of Marketing, 49, 41-50. http://dx.doi.org/10.2307/1251430

Paulík, J., Kombo, F., \& Ključnikov, A. (2015). CSR as a driver of satisfaction and loyalty in commercial banks in the Czech Republic. Journal of International Studies, 8(3), 112-127.

Pirsch, J., Gupta, S., \& Grau, S. L. (2007). A Framework for Understanding Corporate Social Responsibility Programs as a Continuum: An Exploratory Study. Journal of Business Ethics, 70(2), 125-140. http://dx.doi.org/10.1007/s10551-006-9100-y.

Poolthong, Y., \& Mandhachitara, R. (2009). Customer expectations of CSR, perceived service quality and brand effect in Thai retail banking. International Journal of Bank Marketing, 27(6), 408-427. https://doi.org/10.1108/02652320910988302

Porter, M. E., \& Kramer, M. R. (2002). The competitive advantage of Corporate Philanthropy. Harvard Business Review, 80(12), 56-68.

Porter, M. E., \& Kramer, M. R. (2006). Strategy \& Society: The Link between Competitive Advantage and Corporate Social Responsibility. Harvard Business Review, 84(12), 78-92.

Porter, M. E., \& Kramer, M. R. (2011). Creating Shared Value. Harvard Business Review, 89(1), 62-77.

Prahalad, C.K. \& Hamel, G. (1990). The core competences of the corporation. Harvard Business Review, May-June, 79-91.

Rivera, J. J., Bigne, E., \& Curras-Perez, R. (2015). Effects of Corporate Social Responsibility perception of consumer satisfaction with the brand. Spanish Journal of Marketing, 20(2), 104-114. https://doi.org/10.1016/j.sjme.2016.06.002

Sen, S., \& Bhattacharya, C. B. (2001), Does Doing Good Always Lead to Doing Better? Consumer Reactions to Corporate Social Responsibility. Journal of Marketing Research, 38(2), 225-244.

Seo, K., Moon, J. \& Lee, S. (2015). Synergy of corporate social responsibility and service quality for airlines: The moderating role of carrier type. Journal of Air Transport Management, 47(C), 126-134.

Swaen, V., \& Chumpitaz, R. C. (2008) L'impact de la responsabilité sociétale de l'entreprise sur la confiance des consommateurs, Recherche et Applications en Marketing, 23(4), 8-35.

Uusitalo, O. \& Oksanen, R. (2004). Ethical consumerism: a view from Finland. International Journal of Consumer Studies, 28(3), 214-221.

World Business Council for Sustainable Development. (2000). Corporate Social Responsibility: Making Good Business Sense (WBCSD, Geneva).

Zeithaml, V. A. (1988). Consumer perceptions of price, quality, and value: a means-end model and synthesis of evidence. Journal of Marketing, 52(3), 2-22.

\section{Copyrights}

Copyright for this article is retained by the author(s), with first publication rights granted to the journal.

This is an open-access article distributed under the terms and conditions of the Creative Commons Attribution license (http://creativecommons.org/licenses/by/4.0/). 